\title{
BACTERICIDAL AND BACTERIOLYTIC ACTIVITY OF LISTERIA
}

\author{
B.SKALKA \\ Department of Microbiology and Immunology, University of Veterinary Science, 61242 Brno
}

Received April 23, 1991

\begin{abstract}
Skalka, B.: Bactericidal and Bacteriolytic Activity of Listeria. Acta vet. Brno, 61, 1992: $23-28$.

Strains of all known species of the genus Listeria exerted bactericidal and bacteriolytic effects on Micrococcus luteus and bacteriolytic effects on Micrococcus lylae. The bactericidal effect was tested on living cells and the bacteriolytic effect on heat-killed cells of micrococcal strains. The sample of 141 listeria strains examined comprised $80 \mathrm{~L}$. monocytogenes strains, $10 \mathrm{~L}$. ivanovii strains, $45 \mathrm{~L}$. innocua strains, 2 strains each of $L$. seeligeri and $L$. grayi and 1 strain each of $L$. welshimeri and $L$. murrayi. No effect was observed on the other micrococcal species, namely M.roseus, M. kristinae, $M$. sedentarius, $M$. varians and $M$. nishinomiyaensis. The bactericidal and bacteriolytic activity observed in the study can be included in the characteristic properties of the genus Listeria.
\end{abstract}

Listeria spp., Micrococcus spp., bactericidal activity, bacteriolytic activity

Thə genus Listeria now comprises seven species constituting two groups. The first of them comprises Listeria monocytogenes and Listeria ivanovii, both of them pathogenic for man and animals, and Listeria innocua, Listeria seeligeri and Listeria welshimeri. The second group comprises Listeria grayi and Listeria murrayi (Rocourt 1988). This recent classification has introduced a change in that $L$.grayi and $L$. murrayi are no longer classified as a separate genus Murraya as suggested previously (Stuart and Welshimer 1974) and represents also a change as compared with the recent edition of Bergey's Manual of Systematic Bacteriology (Sneath et al. 1986) where the two species were classified within the genus Listeria only as ,species incertae sedis“ (Seeliger and Jones 1986). Moreover, Listeria denitrificans has been transferred to a new genus fonesia as J. denitrificans (Rocourt et al. 1987).

The characteristics of listeria reportedly include the capacity of some strains to produce substances having the properties of bacteriocins. These substances were named,,monocins" ( $\mathrm{S}$ word and Pickett 1961) or ,,listeriocins" (Tubylewicz 1963) and exerted their effects primarily on $L$. monocytogenes strains. More recently however, these substances have been found to be defective bacteriophages of listeria (Bradley and Devar 1966; Ortel 1989).

Mollerach et al. (1988) obtained a $L$. innocua strain producing an exosubstance referred to as , linnocuicin $819^{\prime \prime}$ which showed both bactericidal and bacteriolytic activity. This exosubstance, however, exerted bactericidal and bacteriolytic effects only on one Listeria strain, namely L. ivanovii 818. Moreover, it had a weak growth-inhibiting effect on Micrococcus luteus strain ATCC 9341 , one $L$. welshimeri strain and one $L$. denitrificans strain. Another isolated observation was the production of lysozyme by some $L$. monocytogenes strains, virulent for white mice (Seeliger and Jones 1986). This enzyme is produced in varying intensity by some staphylococci (Varaldo et al. 1980; Lämmler 1989) and exerts its effects primarily on Micrococcus luteus strains (Kocur 1986).

The present study is concerned in detail with a phenomenon described in our previous studies (Skalka 1986, 1988).

Media

Materials and Methods

Brain Heart Infusion Agar CM 375 (Oxoid Ltd.) and Blood Agar Base No. 4 (Imuna) were used. 
Bacterial Strains

Strains Examined

The sample of strains examined comprised 141 listeria strains, namsly $80 \mathrm{~L}$. monocytogenes strains including CC.M 5 576, CC.M 5 879, CCM 5 577, CCM 5 578, CCM 5 880, CCM 5 779, CCM $5883, \mathrm{Li} \mathrm{17/57} \mathrm{and} \mathrm{Li} \mathrm{19/53;10} \mathrm{L.} \mathrm{ivanovii} \mathrm{strains} \mathrm{including} \mathrm{CCM} 5884$ and $\mathrm{Li} 72 / 89 ; 45$ L. innocux strains including CC.M 5885 and Li 71/89; 2 L. seeligeri strains including $\mathrm{Li} 55 / 88$; 1 L. welshimeri strain ( $\mathrm{Li} \mathrm{54/88);2} \mathrm{L.} \mathrm{grayi} \mathrm{strains} \mathrm{(} \mathrm{Li} 31 / 72$ and $\mathrm{Li} \mathrm{70/89);} \mathrm{and} 1$ L. murrayi strain (Li 69/89).

Control Strains

Staphylococcal strains $S$. aureus Mau 87/79, S. hyicus M 51/88 and S. simulans biovar staphylolyticus CCM 3583 were used as controls.

\section{Indicator Strains}

The sample of indicator strains comprised 22 micrococcal strains, namely $10 \mathrm{M}$. luteus strains including CCM 169 and M 15/65; 5 M. lylae strains including CCM 2693 and CCM 2695; 3 M. roseus strains including CCM 839; 1 strain each of M. kristinae (CCM 1690), M. nishinomiyaensis (CCM 2 140), M. sedentarius (CCM 2 697) and $M$. varians (CCM 884).

The CCM strains were obtained from the Czechoslovak Collection of Microorganisms, Brno, and the $\mathrm{Li}$, Mau and $\mathrm{M}$ strains, from the Czechoslovak National Colection of Type Cultures ${ }_{(C N C T C}$, Prague. The remaining strains were isolated in the author's laboratory.

\section{Demonstration of Bactericidal Activity}

A suspension of each micrococcal strain was prepared in saline in a density corresponding to the 1st degree of McFarland's turbidity standard. The suspensions were added in $0.1 \mathrm{ml}$ volumes to $10 \mathrm{ml}$ volumes of melted agar medium cooled to $48{ }^{\circ} \mathrm{C}$. After mixing, the media with the incorporated suspensions were poured into Petri dishes and allowed to solidify. Afterwards the listeria strains to be examined and the staphylococci used as controls were cultured on the surface ot the media using the ,spot-on-lawn ${ }^{\circ}$ technique. The results were evaluated alter $24-\mathrm{h}$ incubation at $37^{\circ} \mathrm{C}$.

Demonstration of Bacteriolytic Activity

A suspension of each micrococcal strain was prepared in saline in a density corresponding to the 4th degree of McFarland's turbidity standard. Prior to use the suspensions were autoclaved at $121{ }^{\circ} \mathrm{C}$ for 20 minutes. The devitalized suspensions were added in $1 \mathrm{ml}$ volumes to $9 \mathrm{ml}$ volumes of melted agar medium. After mixing they were poured into Petri dishes. The subsequent procedure and evaluation of the results were as described above.

\section{Results}

All the listeria strains examined exerted bactericidal effects on the strains of $M$. luteus. On the media into which suspensions of living $M$. luteus strains were incorporated an entirely transparent zone was observed round the listeria cultivation "spots". The width of the zone depended on the potency of the respective listeria strain rather than on its species. Nevertheless, this activity showed least fluctuation and was almost equally intense in $L$. monocytogenes, $L$. ivanovii, $L$. grayi and $L$. murrayi strains and was least pronounced in $L$. seeligeri strains. A remarkably intense activity was shown by $L$. innocua strain bearing the laboratory designation Lin 23 which exerted bactericidal effects also on M. lylae, $M$. roseus, $M$. kristinae and $M$. varians. Of the 3 staphylococci used as controls $S$. hyicus had marked bactericidal effects on all the micrococcal strains, whereas the other two staphylococci showed a negative activity in this respect (Fig. 1).

All the listeria strains showed bacteriolytic effects on the media with incorporated heat-killed suspensions of the cells of $M$. luteus and $M$. lylae strains and did not exert this effect on the remaining indicator micrococci. The manifesta- 


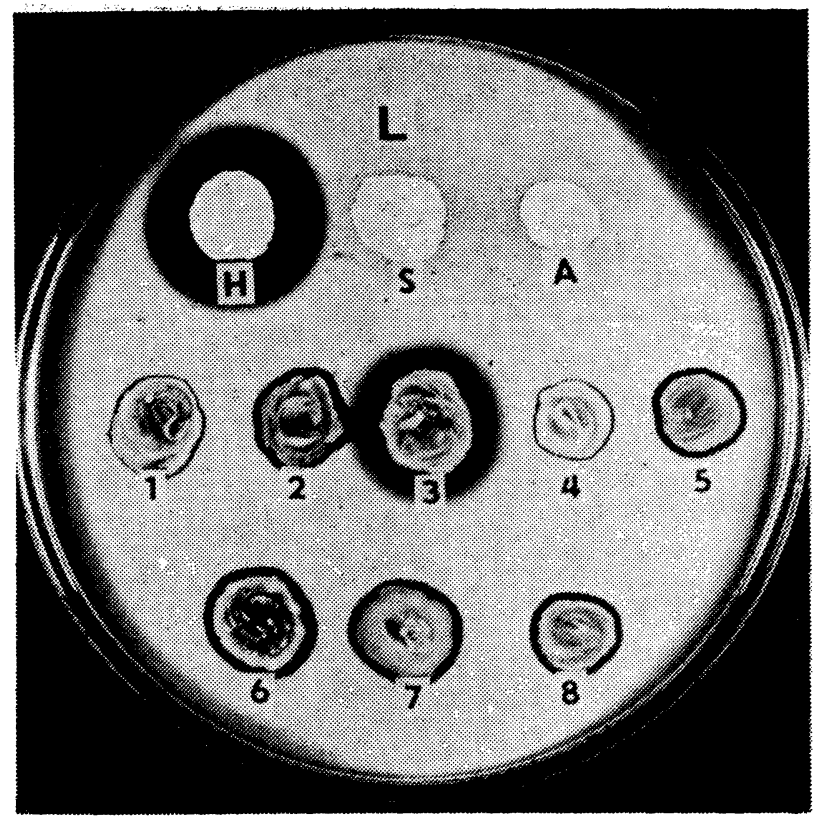

Fig. 1. L, agar medium with living $M$. luteus strain $\mathrm{CCM} 169 ; \mathrm{H}, S$. hyicus $\mathrm{M} 51 / 88 ; \mathrm{S}$, S. simulans biovar staphylolyticus CCM $3583 ;$ A, S. aureus Mau 87/79; 1 , L. welshimeri; 2, L. innocua; 3, L. innocua Lin $23 ; 4$, L. seeligeri; $5, L$. ivanovii; $6, L$. monocytogenes; 7, L. grayi; 8, L. murrayi. Result after 24-h incubation.

Table 1

Effects of Listeria spp. and control strains on Micrococcus spp.

\begin{tabular}{|c|c|c|c|c|c|c|c|c|c|c|c|c|c|c|c|}
\hline \multirow{4}{*}{ Listeria } & \multirow{4}{*}{ No. } & \multicolumn{14}{|c|}{ Micrococcus } \\
\hline & & \multicolumn{2}{|c|}{ lut } & \multicolumn{2}{|c|}{ lyl } & \multicolumn{2}{|c|}{ ros } & \multicolumn{2}{|c|}{ kri } & \multicolumn{2}{|c|}{ nis } & \multicolumn{2}{|c|}{ sed } & \multicolumn{2}{|c|}{ var } \\
\hline & & \multicolumn{2}{|c|}{10} & \multicolumn{2}{|c|}{5} & \multicolumn{2}{|c|}{3} & \multicolumn{2}{|c|}{1} & \multicolumn{2}{|c|}{1} & \multicolumn{2}{|c|}{1} & \multicolumn{2}{|c|}{1} \\
\hline & & $\mathbf{L}$ & D & $\mathbf{L}$ & D & L & D & L & D & $\mathbf{L}$ & D & $\mathbf{L}$ & D & L & D \\
\hline monocvtogenes & 80 & + & + & - & + & - & - & - & - & - & - & - & - & 一 & - \\
\hline ivanosii & 10 & + & + & - & + & - & - & - & - & - & - & - & - & - & - \\
\hline innocua & 44 & + & + & - & + & - & - & - & - & - & - & - & - & - & - \\
\hline innocua $\operatorname{Lin} 23$ & 1 & + & + & + & + & + & - & + & - & - & - & - & - & + & - \\
\hline seeligeri & 2 & + & + & - & + & - & - & - & - & - & - & - & - & - & - \\
\hline velshimeri & 1 & + & + & - & + & - & - & - & - & - & - & - & - & - & - \\
\hline grayi & 2 & + & + & - & + & - & - & - & - & - & - & - & - & - & - \\
\hline murrayi & 1 & + & + & - & + & - & - & - & - & - & - & - & - & - & - \\
\hline $\begin{array}{l}\text { S. hvicus M } 51 / 88 \\
\text { S. simulans }\end{array}$ & 1 & + & + & + & + & + & - & + & $\rightarrow$ & + & - & + & - & + & - \\
\hline $\begin{array}{l}\text { CCM } 3583 \\
\text { s. aureus }\end{array}$ & 1 & - & - & - & - & - & - & - & - & - & - & - & - & - & - \\
\hline Mau $87 \cdot 79$ & 1 & - & + & - & + & - & - & - & - & - & - & - & - & - & - \\
\hline
\end{tabular}

lut = luteus; lyl =lylae; ros = roseus; $\mathrm{kri}=$ kristinae; nis $=$ nishinomiyaensis; $\mathbf{s e d}=$ sedentarius; var $=$ varians; No. $=$ No. of strains; $+=$ antagonistic effect; $-=$ without effect. 


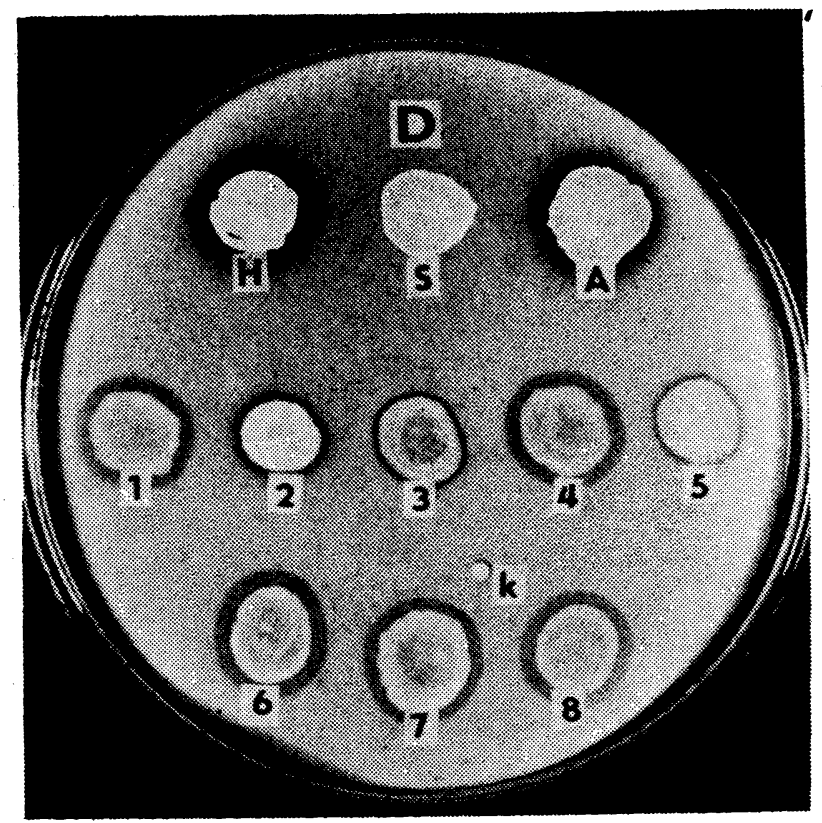

Fig. 2. D, agar medium with a suspension of heat-killed cells of $M$. luteus strain CCM 169; H, S. hyicus M 51/88;S, S. simulans biovar staphylolyticus CCM 3583; A, S. aureus Mau 87/79; 1 , L. velshimeri; 2 , L. innocua; $3, L$. innocua Lin $23 ; 4, L$. seeligeri; $5, L$. ivanovii; 6 , L. monocytogenes; 7, L. grayi; 8, L. murrayi; $k$, accidental contamination. Result after 24-h incubation.

tion of positive bacteriolysis was a zone round the cultivation "spots" generally less transparent than that observed upon the use of the indicator living cells. The bacteriolytic zone in one and the same strain corresponded in size to the bactericidal zone in some cases and was larger or smaller than that in some others. Among the staphylococcal controls bacteriolytic effects on $M$. luteus and. M. lylae were exerted by $S$. aureus Mau 87/79 and $S$. hyicus $M$ 51/88, the bacteriolytic zone shown by the latter being smaller in size than its bactericidal effect. $S$. simulans biovar staphylolyticus had no effects on any of the indicator micrococcal strains (Fig. 2). The results are summarized in Table 1.

\section{Discussion}

The effect of lysozyme, particularly of that produced by staphylococci, on some micrococcal species, is a well-established fact (Satta et al. 1978; Kocur 1986). This enzyme; however, is not produced by all staphylococcal species (Lämmler 1989) and differences in its production may exist even within one and the same species (Kloos and Schleifer 1986). Therefore our choice of control staphylococcal strains was made with respect to the data reported by other investigators (Schindler and Schuhardt 1964; Satta et al. 1978, Varaldo et al. 1980 and Lämmler 1989) as well as in the light of our previous experience (Skalka 1986, 1988).

The fact that strains of all species of the genus Listeria exert bactericidal and 
bacteriolytic effects on both living and devitalized $M$. luteus strains and bacteriolytic effects on devitalized $M$. lylae strains has not been described before. The differences observed in the intensity of the positive effects can be accounted for by both the individual capacity of the strains and by the fact that the inocula of the examined strain were not invariably of the same size. Although in L. seeligeri, L. welshimeri, L. grayi and L. murrayi only one or two strains were tested, it seems reasonable to assume in view of the number of the other listeria species examined in our study that the bactericidal and bacteriolytic activity reported here can be generalized so as to cover the whole genus Listeria. Our results exclude the possibility that the activities observed may be in association with the pathogenity or virulence of listeria. The question whether the effects observed are caused by one or more substances awaits further investigation.

The present knowledge based on our further, hitherto unpublished, results allows us to assume that the antagonism observed is caused by a substance very similar to lysozyme or possibly to $S$. hyicus bacteriolysine (Lämmler 1989). An exception in this respect is $L$. innocua strain $L$ in 23 producing bactericin with a wide-spectrum effect. This strain the activity of which surpasses that of the other listeria as well as that reported for "linnocuicin" (Mollerach et al. 1988) will be the subject of our further study.

The results reported here differ from the descriptions by other writers ( $\mathrm{S}$ word and Pickett 1961; Tubylewicz 1963; Mollerach et al. 1988). Most of these studies were conducted at the time that the present classification of listeria did not exist.

The control strains used in our study corresponded in their effects to the data published previously (Varaldo et al. 1980; Kocur 1986; Skalka 1986, 1988). The observation of Lämmler (1989) who reported the effects of $S$. hyicus on dead $M$. luteus cells was extended by our finding of the effects on dead $M$. lylae cells and on living cells of $M$. luteus and other micrococcal species.

In the light of the present results we suggest that the bacteriolytic and bactericidal activity of listeria described should be included in the characteristic properties of the genus Listeria.

\section{Baktericidní a bakteriolytická aktivita listerií}

Kmeny všech známých druhů rodu Listeria mèly baktericidní a bakteriolytický účinek na Micrococcus luteus a bakteriolytický účinek na Micrococcus lylae. Baktericidní efekt se testoval na živých buňkách a bakteriolytický na tepelně usmrcených buňkách mikrokokových kmenů.. Soubor vyšetřovaných 141 kmenů listerii byl tvořen 80 kmeny $L$. monocytogenes, 10 kmeny $L$. ivanovii, 45 kmeny L. innocua, po dvou kmenech $L$. seeligeri a $L$. grayi, po jednom kmeni $L$. welshimeri a L. murrayi. Žádný efekt se nepozoroval na jiných druzích mikrokoků, a to $M$. roseus, $M$. kristinae, $M$. sedentarius, $M$. varians, $M$. nishinomiyaensis. Pozorovaná baktericidní a bakteriolytická aktivita může doplnit komplex charakteristických vlastností rodu Listeria.

\section{Бактерицидная и бактериолитическая активности пистерий}

Штаммы всех известных видов рода Listeria отличались бактерицидным и бактериолитическим воздействием на Micrococcus luteus и бактериолитическим действием на Micrococcus lylae. Бактери- 
цидный эффект проверяли на живых клетках и бактериолитический - на теплом умерщвленных клетках микрококковых штаммов. Комплекс исследуемых 141 штамма листерий состоял из 80 штаммов L. monocytogenes, 10 штаммов L. ivanovii, 45 штаммов L. innocua, по два штамма L. seeligeri и L. gray, по одному штамму L. welshimeri и L. murrayi. Никакого эффекта не наблюдали на других видах микрококков, а именно $M$. roseus, $M$. kristinae, $M$. sedentarius, $M$. varians, M. nishinomiysensis. Наблюдаемые бактерицидная и бактериолитическая активности могут стать дополнением комплекса характерных свойств рода Listeria.

\section{References}

BRADLEY, D. E.-DEVAR, C. A.: The structure of phage-like objects associated with non-induced bacteriocinogenic bacteria. J. Gen. Microbiol., 45, 1966: 399-406

KLOOS, W. E.-SCHLEIFER, K. H.: Genus IV. Staphylococcus Rosenbach 1884, p. 1013 to 1 035. In: SNEATH, P.H.A. et al. (ed.): Bergey's manual of systematic bacteriology. 1st ed., Vol. 2. Williams and Wilkins. Baltimore, London, Los Angeles, Sydney. 1986. p. 865-1 595.

KOCUR, M.: Genus I. Micrococcus Cohn 1872, p. 1 004-1 008. In: SNEATH, P. H. A. et al. (ed.): Bergey's manual of systematic bacteriology. 1st ed., Vol. 2. Williams and Wilkins. Baltimore, London, Los Angeles, Sydney. 1986. p. 965-1595

LÄMMLER, C.: Characteristic bacteriolytic activities of Staphylococcus hyicus. J. Clin. Microbiol., 27, 1989; $1682-1683$

MOLLERACH, M. E.-OGUETA, S. B.-DE TORRES, R. A.: Production of Linnocuicina 819, a bacteriocin produced by Listeria innocua. Microbiologica, 11, 1988: 219-224

ORTEL, S.: Listeriocins (monocins). Int. J. Food Microbiol., 8, 1989: 249-250

ROCUURT, J.: Taxonomy of the genus Listeria. Infection, Suppl. 2, 16, 1988: S 89-S 91

ROCOU .T, J. - WEHMEYER, U. - STACKEBRANDT, E.: Transfer of Listeria denitrificans to a ne genus fonesia gen nov. as fonesia denitrificans cob. nov. Int. J. Syst. Bacteriol. ,37, 1987: $266-27$

SATTA, G. - VARALDO, P. E.-GRAZI, G.-FONTANA, R.: Bacteriolytic activity in staphylococci Infect. Immun., 16, 1977: $37-42$

SCHINDLER! C. A.-SCHUHARDT, V. T.: Lysostaphin: a new bacteriolytic agent for the Staphylococcus. Proc. Natln. Acad. Sci. U.S.A., 51, 1964: 414-421

SEELIGER, H. P. R.-JONES, D.: Genus Listeria Pirie 1940, p. $1235-1245$. In: SNEATH, P. H. A. et al. (ed.): Bergey's manual of systematic bacteriology, 1st. ed., Vol. 2., Williams and Wilkins. Baltimore, London, Los Angeles, Sydney. 1986. p. 965-1595

SKALKA, B.: Typing of Staphylococcus aureus, Staphylococcus intermedius and coagulase-negative staphylococci by means of staphylococcal bacteriocins. Acta vet. Brno. 55, 1986: 333-324

SKALKA, B.: Isolation of Staphylococcus hyicus strains from healthy hosts and a diagnostic study of the strains (orig. in Czech). Veter. Med. (Praha), 33, 1988: 607-616

SNEATH, P. H. A.-MAIR, N. S.-SHARPE, M. E.-HOLT, J. G. (eds.): Bergey's manual of systematic bacteriology. 1st ed., Vol.2. Williams and Wilkins. Baltimore, London, Los Angeles, Sydney. 1986. p. $965-1595$

STUART, S. E. - WELSHIMER, H. J.: Taxonomic reexamination of Listeria Pirie and transfer of Listeria grayi and Listeria murrayi to a new genus Murraya. Int. J. Syst. Bacteriol., 24, 1974: $177-185$

SWORD, C. P.-PICKETT, M. J.: The isolation and characterization of bacteriophages from Listeria monocytogenes. J. Gen. Microbiol., 25, 1961: 241-248

TUBYLEWICZ, H.: Studies on the bacteriocinogeny of Listeria monocytogenes strains. Bull. Acad. Polon. Sci. (Biol.), 11, 1963: 519-521

VARALDO, P. E.-GRAZI, G.-SORO, O.-CISANI, G.-SATTA, G.: Simplified lyogroup system, a new method for routine identification of staphylococci: description and comparison with three other methods. J. Clin. Microbiol., 12, 1980: 63-68 